\title{
Preference for Prestige: Commentary on the Behaviour of Universities and their Benefactors
}

\section{CHARLOTTE S. CATON*}

The University of Lethbridge

\section{ABSTRACT}

This paper examines institutional behaviour, as perceived and described by individuals who have donated large gifts to private nonprofit (not-for-profit) corporations especially universities. The study improves the understanding readers may have of the means used by Canadian institutions to initiate relationships with individuals capable of making large gifts, of how these relationships are nurtured, of who in the organization influences decisions about the purposes served by gifts from these donors and of how institutional and/or personal prestige are factors in donor-recipient relationships. More significantly, the study explores the degree to which institutions involve major donors as partners in enhancing an institution's reputation for quality. Data reported here were gathered from interviews with donors to universities, hospitals and arts organizations in Toronto. The responses of donors are reported and some differences identified between donors to universities and donors to either hospitals or arts organizations. With the largest generational transfer of wealth in history starting to occur, the findings may prove useful to universities as they compete for charitable dollars with other nonprofit organizations.

* The author thanks Dr. John Holland of the Ontario Institute for Studies in Education, prior to his retirement, for many spirited discussions on the contents of this article and the dissertation on which it is based. 


\section{RÉSUMÉ}

Cet article examine le comportement institutionnel tel que perçu et décrit par des personnes qui ont fait des dons importants à des sociétés privées sans but lucratif, et plus particulièrement à des universités. L'étude permet de mieux comprendre les moyens employés, par des établissements canadiens pour entrer en relation avec des individus en mesure de faire ce type de don, la façon dont ces rapports sont entretenus, qui décide de l'utilisation de ces dons dans l'organisation et comment le prestige, institutionnel ou personnel, intervient dans les rapports donateurbénéficiaire. L'étude explore, de façon particulière, jusqu'à quel point les établissements bénéficiaires associent les donateurs principaux au processus d'amélioration de l'image de marque de l'établissement. Les données qui sont présentées ici ont été recueillies à Toronto lors d'entretiens avec des individus ayant fait des dons à des universités, des hôpitaux et des organismes d'arts. Au travers des réponses des donateurs, nous notons des différences dans les rapports qu'entretiennent les donateurs avec les universités, hôpitaux, ou les organismes d'art. Alors que nous assistons aux débuts du plus grand transfert de richesses entre générations jamais observé dans l'Histoire, les résultats présentés ici pourraient s'avérer utiles aux universités, sachant qu'elles sont en compétition dans l'obtention de fonds caritatifs, avec d'autres organisations sans but lucratif.

Universities and other nonprofit organizations in Canada are generally understood to behave in such a way as to pursue organizational goals and objectives by obtaining funding primarily from governments, customers and donors. Of specific interest here is the behaviour of universities, hospitals and arts organizations as it relates to the acquisition of large gifts from donors. On the one hand there is an argument in favour of pursuing gifts as a means to those ends consonant with institutional goals and objectives and on the other hand, as Thorsten Veblen argued some years ago about universities, of pursuing gifts as an end in itself associated with "notoriety, prestige and advertising in all its branches and bearing" (p. 227). The intention in this article is both to augment work done by researchers in the United States on major gifts from individuals and to attempt to establish the applicability of their analysis to Canadian philanthropy. 


\section{A MACRO-ECONOMIC VIEW OF CANADIAN AND AMERICAN CHARITABLE GIVING}

The big picture of Canadian charitable giving and the importance of gifts from individuals can be briefly summarized. Over an eleven year period, Canadian charitable giving is reported to have grown from $\$ 2.3$ billion in 1980 (Martin, 1985) to $\$ 4.4$ billion in 1984 (Canadian Centre for Philanthropy, 1988) and to $\$ 10.4$ billion in 1991 (Sharp, 1994). Of the 1991 total, individuals are the source of $\$ 8.2$ billion (78.9\%), corporations of $\$ 1.2$ billion (11.5\%) and other sources including foundations of $\$ 987$ million (9.6\%). Sharp's study estimates gifts to religious organizations as being 45 percent of all gifts from individuals. Bird and Bucovetsky (1984) indicate that $\$ 4.4$ billion in donations in 1984 represents 0.72 percent of that year's Canadian Gross Domestic Product.

Such Canadian data can be compared and contrasted with data from the United States for the period 1980 to 1990. Giving USA (1981) estimates donations for 1980 of $\$ 47.74$ billion and in its 1991 edition estimates $\$ 122.57$ billion in gifts for 1990 . The percentage donated by various sources changes little over the decade, with estimates for 1990 showing $83.1 \%$ from individuals, $4.8 \%$ from corporations, $5.7 \%$ from foundations and $6.4 \%$ from bequests. Estimates for gifts designated to places of worship grew from $46 \%$ in 1980 to $53.7 \%$ in 1990 of the total given by individuals in each of those years. Bird and Bucovetsky estimate giving in the United States for 1984 to be $2.15 \%$ of the American Gross National Product, a measure comparable to Canada's Gross Domestic Product.

Most importantly, these data underscore the significance of gifts from individuals as a percentage of total giving and show the parallels between Canadian and American charitable giving. As a percentage of Gross Domestic/National Product the scale of giving in the United States is about two and a half times that of giving in Canada, a significant amount. Still, when calculated on a per capital basis, the difference in the amounts donated by a Canadian and an American do not seem so large. Differences in attitudes about the roles of public and private support of public goods, in the distribution of wealth, in tax benefits and in the actions taken in the 1960s and 1970s by governments that may have acted to "crowd out" private support are among the factors Martin (1975 \& 1985) chronicles for less charitable giving in Canada. The difference diminished between 1980 
and 1990 because Canadian charitable giving grew at a faster rate than it did in the United States. Contributing factors likely include a Canadian population with a greater sense of wealth than in the past, a growing recognition that governments could not continue to fund nonprofits at the levels they formerly did, a greater effort by more organizations to obtain charitable gifts and less favourable tax treatment for certain types of gifts in the United States in 1990 compared with 1980.

\section{LITERATURE REVIEW}

Choosing to focus exclusively on gifts from individuals, as this study does, might be justified solely on the basis of the proportion of total giving derived from individuals, but the fact is that gifts from individuals have merited little scholarly attention in Canada. There is a growing literature on various aspects of charitable giving in the United States including gifts from individuals which, rightly or wrongly, is presumed applicable to Canada. An overview of the breadth of research on American charitable giving could begin with correlation studies undertaken in an attempt to isolate characteristics that might lead to predictive generalities. Works by, for example, Drachman (1983), Dunn, Terkla \& Adam (1986), Leslie \& Ramey (1988), Pickett (1977) and Woods (1988), can be so characterized. A study undertaken by Loessin, Duronio and Borton (1990) provides a typical example. These authors explore the notion that size, wealth and prestige are predictors of fund-raising success. The study finds that voluntary support from all sources directed to U.S. colleges and universities varies with the complexity of institutional mission, that is, whether the institution offers doctoral programs, bachelor degrees only or diplomas based on two years of study. They report that a relatively small number of research/doctoral universities accounts for $50 \%$ of all private support to higher education and that private institutions of a given degree of complexity raise more money than public institutions of the same type. Loessin's investigation of institutional prestige and fund-raising success is ultimately disappointing, since the variables selected to denote prestige - cost of undergraduate tuition and age of institution - are found to have no correlation with dollars raised by research/doctoral universities. Correlation studies of this type have not been done for Canadian universities, because the information 
required is not available from institutions in sufficient detail and is not collected by a third party according to defined reporting standards as is done by the Council for Aid to Education (CFAE) in the United States.

Studies about what motivates an individual to make a gift constitute another major thrust in the literature of gift-giving. Several authors, for example, Martin (1985), Mixer (1993), Minton (1995), and Schervish (1997), have contributed to an understanding of individual motivations or, as Schervish describes them, "mobilizing factors." All of these authors tend to support the notion that there are internal and external motivations. Regarding internal motivations, Mixer describes positive "I" and "we" factors - spirituality, status, family and power - and negative "they" factors - frustration, insecurity and anxiety arising from the actions or inactions of others ("they") which a donor alleviates by making a gift that re-establishes his/her sense of power, status or control. Insofar as external influences are concerned, Mixer includes rewards as in recognition and social mobility; stimulations as in personal requests and vision; and situations as in personal involvement and tradition. Taking a somewhat different approach with a more broadly based constituency, Mount (1996) reports the results of an empirical study of mobilizing factors affecting alumni giving at Laurentian University. Involvement, or joy of giving, and predominance, meaning the degree to which a cause stands out among philanthropic options, are reported as the two most important factors in alumni giving to that institution.

A third area of philanthropic research assumes that a potential donor and a recipient organization interact with each other in such a way as to provide legitimacy and reinforcement to each other's needs. On this topic two Canadians have made significant contributions to the literature, although not specifically in regard to the giving and getting of gifts from individuals. Insights into corporate-university donations are described by Dellandrea (1987) who uses interaction theory to describe the consequences to a Canadian university of accepting two large corporate giftsin-kind. A subordinate theme in Dellandrea's study is the marketing angle corporations seek to advance through their corporate giving program. $\mathrm{He}$ states that the nature of the interaction has progressed from "gift" to "exchange of prestige" to the "buying and selling" of mutual benefits (p. 292). Martin's (1975) book resulted in Revenue Canada demanding 
more rigorous financial reporting of Canadian foundations. Martin (1985) has also written a peripatetic look at philanthropy in Canada, among other countries and cultures. While he comments extensively on giving by individuals in An Essential Grace, the information is presented such as to advance Martin's strongly held view that governments have crowded out donations to the humanistic services, defined as health, education, welfare and cultural services.

An American book about individuals who make very large gifts is Mega Gifts: Who Gives Them and Who Gets Them. In discussion with 33 donors each of whom made a gift of one million dollars or more, Panas (1984) reports donors' frequent use of the phrase "pay something back" and the attraction major donors expressed for the heroic project. He characterizes major donors as wanting to "give to dreams and visions that glow." Panas also notes that major donors give to organizations whose mission they believe in strongly and to organizations with leaders who, in the opinion of donors, can deliver on the vision and get the job done.

It is fair to say that really large gifts are not made to institutions where there is not proper regard for the staff. Conversely, it is true that of the people I interviewed, the million dollar gifts were made to institutions and organizations where there was an unbreakable bond of regard and respect between the donor and the institution's chief staff person ...

There was not one exception. (p. 33)

A study by Odendahl (1987b, p. 230) based on interviews with 200 wealthy Americans delves extensively into the tax repercussions of a large gift. She portrays wealthy Americans as holding an affection for individualism and an abhorrence for bureaucracy: ". . . whatever their political perspective, when study participants discussed their preference for deciding where money would be distributed, it was always in concert with their comments about taxes." Americans, she reports, view tax considerations not as a saving, but as a reduction in the cost of giving. Do factors such as enhanced personal prestige and status affect the giving of wealthy Americans? Odendahl (1987a) indicates that these were not among the reasons most people cited for giving.

If an individual is looking to give something back to an organization that envisions a project - heroic or otherwise - how does this 
prospective donor and an organization get to know and trust each other? Acknowledging that there must be some type of integrative relationship between donor and recipient, Bolding (1973, Preface) states that this relationship needs to "deal with status, identity, community, legitimacy, loyalty, benevolence, and so on, and of course the appropriate opposites." The interactive behaviour leading to the giving and receiving of a gift must therefore be understood as dealing with something more than a monetary transaction. Blau (1986) advances the idea of philanthropy as social exchange and proposes that while the gift passes from donor to recipient, the rewards are bestowed upon the donor not so much by the recipient as by the donor's peers who provide social approval. By extension, then, Blau's observation can be construed as indicating that giftgiving can enhance personal prestige, using a definition of individual prestige as deference to status. Ostrander and Schervish (1990) also support this idea of philanthropy as social exchange:

Like other social relations, that between donor-side and recipient-side actors contains identifiable patterns of interaction; like other social relations, it is a transaction in which both parties get and give as a condition for establishing and maintaining the relation. (p. 70)

This understanding lends support to the notion explored in this study that both personal and institutional prestige are factors in the social exchange involving an individual donor and a recipient.

Cook (1997, p. 333), writes in his critique of the literature on major gifts from individuals, ". . . despite the abundance of research studies, much remains to be discovered - and applied - since what we already know has yet to be put into practice by many nonprofit organizations." In Cook's view, foremost among what is not practiced is the "challenge of making major donors partners in the true sense of the word" (p. 344). Partnership, Cook writes, can mean sharing the institution's vision of the future or being part of the family or community that works for the institution's success. Thus, this discussion of the literature turns its attention from individual behaviour to institutional behaviour.

Of particular interest is the model of university economic behaviour posited by Garvin (1980), and similar models for hospitals and the arts developed by Newhouse (1970) and Hansmann (1981), respectively. 
Garvin, Newhouse and Hansmann each assume nonprofit organizations exist in a market environment where there is competition for customers and donors, among other sources of revenue. Garvin makes no claim of superiority for his model of university decision making over others, for example, the collegial or organized anarchy models, but does claim that the others are limited by their internal focus whereas his model positions the university in a competitive economic environment.

As described by Garvin, economic decision making at research universities shows a preference for higher prestige ("prestige maximizing") and Newhouse, similarly, characterizes hospitals as prestige maximizing. Hansmann posits several models of economic behaviour for performing arts organizations and then allows that when finances are not a constraint, decision makers show a preference for higher quality programming. Garvin's research university may be understood as an institution that offers programs leading to a doctoral degree in many of its faculties and schools. Throughout this paper, as in Garvin's study, the definition of prestige when referring to an organization shall be a "reputation for quality." Individual or personal prestige is better understood using an alternate definition that is partially provided by Webster's Third New International Dictionary (1981): "Standing or estimation in the eyes of the people: reputation ..." and by Presthus (1962, p. 36) who refers to prestige as "the deference attached to each position" within an hierarchy. In the context of this paper, individual prestige shall be understood as "deference to status" where status or standing is based on reputation and financial capability. Notwithstanding the preceding meanings attributed to "prestige," use of the word requires caution because the first definition in many dictionaries, including The Oxford English Dictionary (1989), is "an illusion," as in conjuring.

Garvin asserts that economic decision making by faculty and administration in research universities shows a preference for higher prestige. Faculty, for their part, place an emphasis on the reputation for quality of their department. Administrators are generally more concerned about the reputation of the institution as a whole which, Garvin argues, is a function of the prestige of its separate departments. In essence, his argument is that those universities that allocate resources to acquire more faculty and higher quality faculty and students show a preference for higher prestige 
and that this model better explains university economic behaviour than other plausible models, such as profit maximization, revenue maximization or income maximization. Newhouse describes hospitals as prestige maximizing with quality strongly related to the role of the medical staff in decision making. Performing arts organizations are characterized by Hansmann as quality maximizing when their financial position is relatively stable and the preferences of the dominant decision-maker and the organization's donors are persuasive with the board of directors. Similar conditions are presumed by this researcher to affect decision making favouring higher quality programming in visual arts organizations.

Garvin's choice of "prestige" to characterize favourably the preference of university decision makers is somewhat surprising given the word's excoriation by Veblen (1918). His description of university behaviour in the early part of the twentieth century likens the pursuit of prestige to "notoriety, . . . advertising." The arguments about the pursuit of higher prestige made by Garvin and Veblen, however, differ in at least two important ways: first, Garvin posits that higher prestige is the goal of faculty and administration, albeit with different but overlapping points of emphasis, whereas Veblen characterizes higher prestige as the goal of an institution's governing board, "men of affairs" whose capacity to understand the real work of a university he found highly questionable. Secondly, Garvin argues that higher prestige, is an end in itself rather than, as Veblen would have it, the means to some other end, namely, impressing potential donors "a highly speculative line of enterprise offering a suggestive parallel to drawing a lottery" (pp. 138-139). Veblen, unlike Garvin, does not let his reader forget that the notion of conjuring is inherent in the etymology of "prestige." Of interest in this study is the perceptions donors have of using the word prestige in connection with nonprofit decision making. Trustworthiness, after all, is described by several authors (Weisbrod, 1988; Krashinsky, 1986) as an essential factor in the very existence of nonprofit organizations.

\section{RESEARCH DESIGN}

The empirical portion of this study entailed face-to-face interviews with 28 donors who had each recently made a large gift to a university, hospital or arts organization in Toronto, Canada. Their names were 
identified from segmented lists of donors published by various institutions in the city. From among two research universities, six teaching hospitals and three performing and four visual arts organizations in Toronto, a group of 28 individuals representing 12 university donors, eight hospital donors and eight arts donors accepted an invitation to participate in the study. Since the focus here is primarily on universities, special attention is given in this paper to the remarks made by the 12 interviewees who made their gifts to universities. The researcher neither suggests nor implies that these respondents comprised a random, stratified sample and acknowledges that these were donors who were prepared to talk about their gifts; they represented about half the number invited to participate.

Interviewees made gifts ranging from $\$ 50,000$ to $\$ 2$ million to each of the three classes of nonprofit organizations. Those interviewed included men and women as well as one couple. Some interviews took place in people's homes, but more were done in offices. All respondents were asked to recall details of a specific large gift they had made. In most cases the gift was made about a year and a half or two years prior to the interview. The quality of the data arising from the recollections of these donors is undoubtedly affected by the passage of time and also by how perceptively the interviewer captured both what was said and what was implied by the respondents. To allow Journal readers the opportunity to weigh for themselves the comments made by donors, some are quoted directly in the paragraphs which follow. When necessary to improve clarity, some quotes have been lightly edited.

The interview questionnaire had three parts. In the opening section donors were asked to describe their own gift and the way the relationship with the receiving organization developed. The middle section asked for one of five fixed responses ranging from "strongly agree" to "uncertain" to "strongly disagree" along with any commentary the donor wished to make to a series of eight statements. The third section explored the hypothetical relationship between institutional decision making or behaviour that seeks to enhance prestige and donor decision making. Some interviews lasted barely thirty minutes, others nearly ninety minutes. 


\section{FINDINGS}

The findings reported here are subdivided into sections that characterize the philanthropic milieu within which charitable giving occurred in Toronto at the end of the 1980s; that document some differences amongst universities, hospitals and arts organizations in institutional behaviour and donor motivation leading to a large gift; that highlight some similarities and a few differences between Canadian and American attitudes to charitable giving and that explore personal and institutional prestige as factors in the giving and getting of large gifts.

\section{The Philanthropic Climate of Toronto, Canada}

Donors exist in a philanthropic milieu or environment. One area can be exceptionally generous and another with similar demographics exceedingly stingy. Some Toronto donors who had themselves solicited gifts admitted to being a little jaded by their experiences. One assessed the city's philanthropic climate in these words:

It stinks. Toronto is not known world wide as a giving city. It is getting better because the old school tie boys are dying out and a new breed, often American presidents of branch plants, is moving in with razzle dazzle ideas.

Another donor, who qualifies as one of the "old school tie boys," echoed this sentiment: "I'm surprised by the lack of interest by people who are well fixed and don't pull their own weight."

Respondents stated that in their opinion Toronto nonprofit organizations compete in a healthy way for donors, just as firms in the for-profit sector compete for market share. Competition to ensure that "names," that is people with money and connections, attend special event fund raisers was judged by some to be excessive. Toronto was characterized by respondents as a philanthropic underachiever in relation to its potential for large gifts. None of the donors decried the large campaign goals being set by universities, hospitals and arts organizations and all understood that the success of these campaigns is predicated on attracting a sizeable number of large gifts from individuals. 


\section{Taxation and Government Funding of Nonprofit Organizations}

The Canadian government offers a tax credit to individuals based on a percentage of the dollar value of charitable gifts reported for income tax purposes; provincial taxes owing are also affected by this credit. At the time of this study, a gift of $\$ 100,000$ generated a combined federal and provincial (Ontario) tax benefit of about $\$ 46,000$. The degree to which this credit can be claimed is limited by the donor's taxable income with any unused portion carried forward for up to five additional years. Donor attitudes about tax benefits for gifts echoed previously mentioned reports of attitudes held by American donors. No one thought that tax benefits stimulate the inclination to give, which is to say none of the respondents thought that people made a gift only to obtain a tax credit, without consideration of the purpose the gift would serve. Rather, with tax relief, participants thought more people could afford to make a large gift and to make an even larger gift than they might initially have considered, possibly by using the money not paid in taxes to purchase an insurance policy or a zero coupon bond to replace wealth to be distributed to children or other heirs. One respondent asserted, "In the United States and Canada donors perceive tax relief as an entitlement; it's the way our system works." Another donor observed that philanthropy acts to lessen the pressure on government to provide certain [higher] levels of service. Donors in both countries might therefore be described as viewing tax relief as the carrot and paying higher taxes as the stick.

Amongst interviewees there was no sense that government funding to nonprofit organizations was crowding out donations. One donor responded to a question suggesting that government support resulted in a decrease in private support by saying, "You've got it backwards. Donors increase their support when government increases its share of funding." The reason why this should be the case was explained by a respondent who described government support as a "seal of approval" for a project or an organization, thereby helping donors avoid "losers." Some donors did comment that government funding might have crowded out donors ten or fifteen years ago, but in the words of one, "things have changed and the days of large government increases are long gone."

Canadian donors offered none of the strong anti-government feelings voiced by donors in the United States, summarized earlier. This is a 
significant difference between donors in the two countries. Most Canadian donors stated their approval of the partnership between government and private donors in funding nonprofit organizations. In general, there was a distinctly positive tone to respondents' comments about government involvement, providing government funding did not "prop up inefficient and badly managed nonprofits." One reclusive donor stated, "Personally, I think if the government is involved in solving a problem that I'm involved with, then more will happen. But, I don't like government generally."

\section{Board Service and Campaign Leadership}

Interviews generally began with the question "How did you get involved with the organization to which you made this large gift?" Donors to hospitals and the arts invariably answered that they had been invited to serve on the institution's board or the board of the organization's foundation. The answers from university donors were considerably more diverse, given that fewer than half of them served on the board of governors and only half were alumni of the university to which they made the gift under discussion. Other relationships that led to university gifts included: one donor's relative taught at the university to which the gift was made, another individual who had recently moved to Toronto got very interested in a project suggested by a staff member and long-time friend, a third gift was made by a retired faculty member to his department, and another donor was identified and pursued by a faculty member who shared the donor's interest in a particular art form.

Being asked to serve on the board of university, hospital or arts organization by the Premier of Ontario or some other person held in very high esteem was a memorable moment in the lives of respondents. Several took the time to describe in considerable detail how and when they had been invited to serve on a board. Indicative of the emotion that recalling this event had for them, is the fact that several throats were cleared and body positions changed during the story. One donor acknowledged the connection between his colleagues' approval and prestige when he stated: "Serving on a board is not without prestige. Among my peers it means something, especially among those who are themselves involved. For me its a case of personal satisfaction." Respondents also mentioned that board service could lead to a loss in 
prestige. This might arise in the case of a board member who takes an unpopular stand on an important public issue.

Board members spoke about their role in a capital campaign to make leadership gifts. Several of those who made such gifts indicated that it was by far their largest gift and certainly much more than they had originally intended to give. Even so, half of those respondents serving on a university board admitted making gifts below their financial capacity. Two of six university board members admitted that they gave the least they thought they could without incurring the loss of other board members' respect. Another announced that he made a much larger gift to a prestigious university in the United States from which he graduated, than he did to a Toronto university campaign with which he was intimately involved. When asked why, he indicated partly because of social blackmail and partly because the institution is and intends to remain preeminent: "The U.S. university pushed very, very hard."

Among the questions asked of each respondent was whether an organization's fund-raising success depended first and foremost on a committed board. Twenty-three of twenty-eight respondents either agreed or strongly agreed that it did; only one person disagreed with the remainder indicating they were uncertain. Those that disagreed or were uncertain were all university donors. A university board member offered this analysis of the role of different types of boards in fund raising:

The board of a university is the least related to fund raising of the three areas: hospitals, universities and the arts. That does not mean a university board is at a disadvantage. People aren't recruited to a university board for that purpose, but rather for other areas of expertise. In arts and hospitals, fundraising capability is about the biggest reason for recruitment.

Extending this perspective, another donor stated:

You need to select and empower an individual to raise funds. Whether he or she sits on the board is no matter. In my experience there is no one answer ... At the very least there has to be agreement among the board, management and fund raisers on the organization's strategic direction.

Another university donor added this insight: 
Leadership must come from the president or CEO. That is first and foremost! If the board has prestige, meaning good connections, the institution will get twice as much money than if it has no prestige. Board cohesiveness with top management is crucial, for through it comes involvement in the institution and self-propelled enthusiasm.

In summary, different organizations are recognized as requiring different types of expertise and skills from their board members. While hospital and arts organizations tend to recruit board members who can raise funds, universities seek board members who bring other skills and perspectives to the board table. The process of selecting, showing deference and empowering individuals other than board members to carry out fund-raising responsibilities requires a considerable investment of time and often requires more than a little humility on the part of others including the organization's CEO and board members because a prospective chairperson knows that a large capital campaign puts his or her personal prestige at risk should the campaign not achieve its goal.

\section{Factors Common to a Large Gift}

Early in the interview, each donor was asked to describe what led to the particular gift under discussion. Of interest to the researcher were the motivating factors and details of the transaction such as who initiated the interaction, what degree of partnership might have existed prior to the major gift, who suggested the purpose the gift might serve, who was involved in asking for the gift, and what, if anything, was negotiated? These questions afforded the opportunity to document any differences that might exist in the way representatives of the three types of institutions interacted with prospective donors.

Motivating Factors. As a generalization, university donors seemed to be largely motivated by what was previously characterized as "I/We" internal motivations. More than half of university donors used words such as "I determined," "I decided," or "I began" to describe the initiative each took in starting the major gift process. These donors had previously made annual gifts in the $\$ 1,000$ range, attended university events organized to thank these donors and, thus, were known to the institution's president and/or development office staff. Still, at the time the 
donor decided to proceed, s/he contacted the president who then played a direct role by meeting with the donor to gauge the donor's interests and assess what level of gift the donor had in mind; by offering suggestions about how a gift at or above the level the donor had in mind might assist the university; by involving others - senior administrators, deans or departmental chairs - in meetings with the donor; by directing development office staff to prepare one or more written proposals for the donor's consideration; and, finally, by attending a reception or holding a dinner party in the donor's honour upon confirmation of the gift. In those cases where the president was not involved, gifts were stimulated by personal requests and personal involvement. The two largest gifts supported endowed chairs and entailed the extensive participation of faculty members. None of the university gifts appears to have been motivated primarily for reasons of recognition, social mobility, or tradition.

There was some assertion of "I/we" motivation amongst hospital donors, but it did not dominate the remarks made by this group as it did with university donors. Family tradition, a sense of civic responsibility, or gratitude for being kept alive were clearly evident as mobilizing factors. Art donors projected a modest sense of "I/We," especially in combination with a strong family connection to an organization, but donors to arts organizations generally manifested stronger external motivations than were noted for university and hospital donors. Relevant factors included personal involvement arising from serving on the board, friendships, peer recognition and social mobility. The CEO's of hospitals and arts organizations were not mentioned as being directly involved in the giving and getting of gifts, presumably because board members held this responsibility.

During the interviews, the impact of negative motivating factors on charitable decisions was also mentioned. Several graduates did not make gifts to their university out of frustration with some specifically mentioning that they had never once been invited by a president, principal or dean to a luncheon or private meeting. Their comments strongly suggested that in their view, universities are not very good at showing deference to status and/or building partnerships. These respondents believed that although they were leaders in the business community with the financial capacity to assist the institution, this status seemed to be of no 
importance to their alma mater. Donors perceived universities as tending not to recruit and involve members of the community, their own alumni, and especially prospective major donors to the same extent as the arts and hospitals have learned to do.

Only one of the university respondents spoke of a desire to give something back, although several hospital and arts donors did. University donors were comparatively joyless about their gifts as were the hospital donors who gave because it was deemed their civic responsibility. The most joyful were hospital donors who were thrilled to be alive or to have loved ones still alive. In comparison with others, arts donors conveyed the most real pride when speaking about how they felt about their gift, perhaps because peer approval was more highly sought and freely given, or because they were able to witness and enjoy the benefits of their charitable giving in more socially satisfying ways than university and hospital donors typically do.

Choice of purpose. Gifts from university donors supported a wide variety of purposes. Amongst the group of twelve donors, four made gifts in support of building projects, three supported endowed faculty positions, two funded endowed student scholarships, two supported academic program initiatives and one made an unrestricted gift. While endowed chairs, included among the endowed faculty positions, provide some support for research, no other gifts in support of research were made by this group. There is no apparent reason for this beyond the comment made by one donor who said that to do anything significant in the area of research would take more funding than he was prepared to commit.

In contrast, five of the eight hospital donors made unrestricted campaign gifts. The purpose of each hospital campaign, however, was quite narrowly focused, on new construction and renovations or on raising endowment funds for research. The scope for designating a gift was therefore much smaller than would be the case for a university's multipurpose capital campaign. Gifts to hospitals not involved in a campaign included two gifts to specific research programs and another to endow a medical chair. Individuals who donated annually to the arts, with one exception, also had specified a level of commitment to a building campaign. The lone exception planned to increase his annual support very substantially during the building campaign in the belief that gifts for operations would decline. 
Interviews with donors to the arts and to hospitals about the purpose of their gift served to highlight a couple of points. In cases where gifts were made to hospital research programs, a doctor, not a board member, initiated the interaction with the donor, who was not always a patient. A second observation is that hospitals and the arts offer their donors relatively simple choices that communicate to prospective donors a clear message about institutional goals. This is in comparison to a typical campaign presentation to university donors of a very wide range of choices about the purpose a gift might serve. On the one hand, greater choice may widen the appeal to donors with diverse interests; on the other hand, the range of choices may suggest that the institution has no defined goals with the result that donors appear able to nudge the institution in one direction or another. This is a communications conundrum with which universities constantly grapple. That said, university decision making was judged incomprehensible by some donors who sat on university boards of governors.

Building and Program. Three of the four university donors whose gifts supported building projects were initially reluctant but ultimately convinced to make a "bricks and mortar" gift because of the impact the new or renovated facility would have on people or programs. In other words, the building only served as a means to some other end of interest to the donor. The responses gathered here suggest that major donors to universities are no longer interested in funding building projects, unless their imagination is captured by the benefits to students, professors or programs.

Donors to university building and renovation projects were more likely than not to say they wanted to be consulted about the project as it unfolded: "I either get some hands-on participation in the project or I won't contribute." Another donor stated that she expected to be consulted and would offer an opinion or two about the design. Donors of endowed chairs were less likely to be interested in consultation, although one admitted that he looked forward "with surprising enthusiasm" to the one-on-one annual breakfast meeting with the person holding the chair he endowed. Many other donors, but certainly not all, wanted periodic updates and a report on goals and outcomes achieved as a direct result of their gift. The majority of donors to all three classes of nonprofits did not 
expect to make a major gift and move on to other projects; these donors expected a continuing relationship with the institution, faculty, school or department, but the word partnership was not used.

Making a Difference. "I thought my gift could make a difference." Nearly every published article on gift-giving lists this as the reason most people cite for making a gift, but it is, nonetheless, surprising how frequently interviewees actually used those very words. Because much is left unsaid in this statement, the context of the discussion and the donor's actions warrant further scrutiny. Are donors saying they thought the gift could make a difference to them personally and/or to the institution?

Whereas hospital and arts donors were with one exception convinced their gift had made a difference, university donors were not entirely convinced that this was the case. One donor whose gift established a scholarship expected that it would make a difference to someone who might otherwise be prevented from attending university for financial reasons and was disappointed to learn that the recipients were generally from families he judged to be prosperous. Another donor indicated disbelief that it could take two years to find a suitable person to hold the chair he had endowed. This donor expressed annoyance, even hurt, that during this interval not one university representative had shown the courtesy of telephoning to provide periodic progress reports.

Some university donors believed their gifts would make a difference to a key area of a university's stated needs and trusted university leaders to ensure that it did. Trust is a salient term here. The level of trust between donor and university seemed to be on a different level than that linking donors with the other two classes of institutions. This may be because university donors were less directly involved with the institution or because the ultimate beneficiaries - students and faculty - were more distant in age or culture, or because donors did not expect to understand the exact difference their gift might make. For each donor who found a way over time to develop trust in the institution, one wonders how many prospective donors are waiting for a university to take the first step in building a trusting relationship.

Recognition. None of the university donors admitted asking for an honorary degree in recognition for their gift, although donors to all three classes of nonprofits named this as a university's best reward for a very special donor. Recognition is a negotiable, but generally the topic is raised 
by the recipient. In one case where there was a desire to memorialize a deceased spouse, recognition was a factor from the start. Many donors insisted that they wanted no recognition, believing it would only generate more requests for money. Some were persuaded to accept public recognition based on the institution's argument that it would inspire others to make gifts. Ego and mortality were acknowledged as playing a part in a person's decisions about philanthropic gifts, particularly when a career began to wind down. With respect to recognition, there were few differences among the donors to the three classes of institutions. The respondents did not proclaim either verbally or otherwise that they were looking to have their name on a building. In fact, several donors cringed at the thought of possibly having their name associated with a building or room which in future might be found with peeling paint and damaged furniture.

Prestige. In deciding to structure the interview so that donors would first talk about their own gift with minimal prompting or leading, the researcher hoped to accomplish two things: firstly, to document how a donor and recipient institution interacted and secondly, to set the stage for some follow-up questions about what role one factor - prestige might play in the giving and getting of gifts.

During this part of the interview, donors were first asked to comment, if they wished, on the hypothesis that institutions seek to raise money for projects that enhance institutional prestige or stature. University donors found the premise more contentious than did either hospital or arts donors. One agreed only on the understanding "this means an attempt to achieve excellence in its field." Another stated "Campaigns pick projects that are likely to trigger a response." A third asserted, "You can't generalize about the premise; it's too broad." All participants undertook, however, to continue with the interview.

The characteristics that donors thought made one university more prestigious than others of the same type are as follows, presented in order of the number of times each was mentioned: reputation for high quality ("world-class") programs comprising instruction as well as research (5 mentions); prominent professors, visiting professors and lecturers ( 4 mentions); quality research signified by Nobel Laureates among other internationally recognized researchers and scholars (4 mentions); reputation for enrolling the best students and producing quality graduates ( 3 mentions); single-minded pursuit of excellence 
(2 mentions); breadth and size of operation ( 2 mentions); and other factors such as availability of scholarships, age, a venerable but not musty aura and an ambiance that projects the excitement of ideas.

In the minds of very generous university donors, prestigious universities have the most prominent professors, the highest quality teaching and research programs and the best students. This represents reasonably good agreement with the variables in Garvin's model of economic decision making, discussed previously, but in comparison this level of agreement is considerably less than that between hospital, arts donors and the respective decision making model for each of these institutions. The eight hospital donors all provided at least one of two answers: quality/reputation of the medical staff ( 5 mentions) or research capability (5 mentions). Other characteristics of prestige mentioned included quality of patient care ( 3 mentions). Arts donors mentioned either quality of performers ( 5 mentions) or quality of collections ( 3 mentions), depending on whether their involvement was with the performing or visual arts.

The list of characteristics is interesting for what is not mentioned. Some characteristics donors mentioned in regard to hospital and arts organizations were not mentioned in regard to university characteristics: two hospital donors mentioned "influential board members," a hospital donor and an arts donor each mentioned "top notch management and leadership," and one hospital donor mentioned "advanced equipment." Not one donor mentioned "endowment" in relation to any of the three classes of organizations, even though endowment is used extensively in the United States as a basis to rank universities. Also, no one mentioned "library" as a characteristic of a highly prestigious university.

One surprising result of asking about the basis of university prestige was that four of twelve university donors found it easier to identify salient characteristics of higher prestige in hospitals than in universities. In fact in two of these cases, no prestige characteristics of universities were presented; in the other two cases, comparative comments were made. One university donor with considerable experience on the board of a hospital stated, "with respect to hospitals, one knows the reputation of the doctors for curing people, but assessing the quality of personnel in a university is much more difficult." The second comparative comment is as follows: 
Big money is given mostly for selfish reasons. People want to get the best doctors locally, provide the most comfortable rooms or see the best ballet dancers. You get big money from people who appreciate quality.

Not one example for giving to a university is contained in this comment by a university donor and board member. When combined with the comments and inferences that accompanied this quotation, its meaning becomes: not only do you get big money from people who appreciate quality, but the object or institution chosen by the donor to receive funding must convey or reflect to a donor's peers an awareness of the donor's discerning appreciation for quality. In other words, the desired deference to status comes from one's peers, as Blau (1986) hypothesized, a deference which turns on the issue of appreciation for quality. One's peers, however, can be somewhat fickle. Several pointed out that if donors are perceived to have tried to buy status by making a big gift or to have not given in proportion to their capability, respondents would hold such donors in lower regard. Furthermore, if the receiving institution gave excessive recognition to a donor and if the donor's gift was not a sizeable percentage of the project's cost, then those representing the receiving institution would themselves be held in lower esteem.

Taken together, the two comparative comments by university donors indicate a conundrum: donors want to associate themselves with programs and institutions of high quality, but finding and assessing quality in universities is much more difficult for donors than assessing quality in some other nonprofit organizations. This problem of information asymmetry, and ultimately trustworthiness, poses a particular challenge to university-donor relations. A greater investment in two-way communications, inherent in most working partnerships, should lead to an understanding of what measures might prove helpful to a donor for determining quality because as one respondent stated, "quality is difficult to define and each definition has its own, emotional, proponents."

When asked whether they would be more rather than less inclined to support a project associated with one of the characteristics of higher institutional prestige that they named, nearly every donor weighed their answer carefully, without always responding to the question. Typical of the responses from visual arts donors is this: 
Well, if you haven't got the space to display the prestigious collection which you own, then no one knows whether you've got any prestigious stuff or not. We're not talking about money at the margin. It's the heart of the matter.

A hospital donor stated:

Half the donors don't care one whit about the pitch or what the gift will do. They give because they know they'll benefit sooner or later and, besides, they know it's their community responsibility.

Another hospital donor exclaimed:

We're seeking funds for research. It's crucial to quality in a tertiary hospital. We're not looking for prestige or stature per se, but we know that to attract the doctors we want, we've got to have more funds available than the Medical Research Council can provide. It's peer recognition that gives a hospital its reputation.

Responses from university donors proffered a considerable lrange of opinion, such as:

The area I supported wasn't something I'd thought much about before the President brought it up. I see the support I gave as contributing to the stature of the institution, but the idea was not very much in my mind when I made the gift. The institution told me this project was important, and I believed them.

Another university donor stated:

The university gave me some options when they approached me for a gift, and I selected one that appealed to me. I never considered whether it contributed to the stature of the institution. It's what they said they needed.

A third remarked, "The job of external relations at most universities is not well handled . . . You are disinclined to support profs doing the same old thing. .."

The evidence thus strongly suggests that personal and institutional prestige play a part in the giving and getting of gifts. Prospective major donors respond positively to a show of deference; some even respond 
negatively when it is not forthcoming. There was a conscious attempt by several university donors to find more congruence than at times seemed warranted between the prestige characteristics they advanced and the purpose of their own gift. That said, economic behaviour that favours programs with a reputation for quality teaching and research, involving the highest quality faculty and students should find considerable favour with donors.

\section{SUMMARY COMMENTS}

The data gathered in this study chronicle views of major donors, expressed at a particular point in time. Canadian philanthropy is evolving, in part because the federal government is actively encouraging gifts by offering enhanced tax benefits over those described earlier, in part because of changing demographics and in part because organizations are beginning to respond to the challenge of building relationships with individual donors. Whether or not the tax benefits and organizational behaviour can be sustained remains to be seen. If ego and mortality are factors in charitable giving as indicated by respondents, members of the baby boom generation will almost certainly transfer a portion of their wealth to organizations and causes whose behaviour they admire. Given that a larger percentage of baby boomers attended university than in preceding generations, it will be interesting to follow whether donations to universities grow at a faster or slower rate than donations to other charitable organizations. Comments reported here suggest that universities could take steps to enhance the likelihood that any increases are directed to them.

First, Canadian universities must find new ways to bring the people of ideas - faculty and students - together with people from outside the university who are interested in ideas and have the capacity to make large gifts. Advisory councils and "boards of visitors" are used by colleges and universities in the United States for this purpose. Canadian university development offices have relatively recently started programs in which major gift officers meet periodically with prospective donors. The information exchanged during these visits should be used to develop personalized communication strategies between prospective donors and representatives of faculties, schools and departments in which the donor has an interest. Prospective donors can get a better sense of quality at the 
program level and about students and faculty by directly interacting with these people than by meeting with the president. Direct involvement of deans and faculty in building relationships with donors was found in this study to lead to endowed faculty positions; donors who met with the president supported more diverse institutional purposes.

Secondly, words such as status, stature and quality are acceptable to donors, but "prestige" has too many connotations to make it a word that donors trust. Prestige, whether it is taken to mean a reputation for quality or deference to status, is a concept that is not alien to donors; rather, it holds a certain risky attraction that would be unacceptable to donors concerned with peer approval. Prospective donors behave in a vigilant manner to guard against institutional sleight of hand or conjuring by requesting additional information and by controlling the time within which a decision is reached. Given the association of "prestige" with illusion, any institutional emphasis on higher prestige, per se, would likely be a barrier rather than a bridge between an institution and a potential donor. The notion of a gift as a source of funding to build a higher reputation for quality would be acceptable especially if a basis for determining what characteristics will be used to assess the achievement of higher quality is spelled out; a gift to pursue higher prestige would, however, be greeted with considerable skepticism, if not outright scorn. University behaviour, that clearly communicates pursuit of an enhanced reputation for quality is likely to be rewarded by donors, providing the word prestige is never used.

Thirdly, true donor-recipient partnerships were most evident amongst donors to arts organizations; donors readily spoke without prompting about feeling part of a family. Power in an arts organization rests far more directly with the board than in a hospital or university where power is shared with doctors and professors. Hospital donors hold doctors in great awe and have great pride of association with the hospital and doctors that they support. There is a sense of partnership - one between people of money and people with lifesaving knowledge and skills. University donors also conveyed pride of association, albeit one more often than not associated with nostalgia than awe. Thoughts of university brought back fond, sometimes bittersweet, memories of a time of high hopes and good friends. Donors felt a sense of attachment but not of partnership. One university donor did convey a sense of real partnership when he recalled the 
excitement of being involved with a new university. There was a sense of energy and creation - new people, ideas, buildings and campus. Now, he thought, university decision making seemed little more than peace-keeping among the stakeholders. Increased contact with faculty and students might help donors gain sense of the energy and excitement shared by those intimately involved in the discovery and discussion of ideas.

While decidedly beyond the scope of this inquiry, the question of why there is so little research on nonprofit organizations undertaken in Canada is perplexing. Much depends on the quality of the decisions made and actions taken by nonprofit organizations, as Canadians know all too well from the recent inquiry into tainted blood and the Canadian Red Cross. Nonprofit organizations affect the quality of almost everyone's life, and they employ, either in a paid or volunteer capacity, a very large segment of the population. Yet, the Canadian economy is persistently described and generally understood as entailing public and private rather than public, private and nonprofit sectors. Some might argue that Canadian nonprofits are heavily subsidized by government and are therefore government organizations. Such arguments underscore the need for a better understanding of nonprofit organizations and the variations in funding patterns in countries around the world. More to the point, with governments reducing funding to nonprofits, there is all the more reason to understand the role they play in shaping the quality of life. Research into the historical, social, political, legal and economic aspects of Canadian nonprofit enterprise is needed to generate a better appreciation of the important, even distinctive, characteristics of the Canadian nonprofit sector.

\section{References}

Bird, R.M., \& Bucovetsky, M.W. (1984). Private support for universities. Toronto, ON: Government of Ontario.

Blau, P.M. (1986). Exchange and power in social life. New Brunswick, NJ: Transaction Books.

Bolding, K.E. (1973). The economy of love and fear: A preface to grants economics. Belmont, CA: Wadsworth. 
Canadian Centre for Philanthropy. (1988). Canada gives: Trends and attitudes toward charitable giving and voluntarism. Toronto, ON: Canadian Centre for Philanthropy

Cook, W.B. (1997). Surveying the major gifts literature: Observations and reflections. Nonprofit Management and Leadership, 7(3), 333-347.

Dellandrea, J.S. (1987). Corporate support and university development. Unpublished doctoral dissertation. University of Toronto.

Drachman, S.S. (1983). Factors accounting for variations in levels of private giving to higher education. Unpublished doctoral dissertation. University of Arizona.

Dunn, J.A., Jr., Terkla, D.G., \& Adam, A. (1986). Comparative studies of fundraising performance. In J.A. Dunn, Jr., (ed.), New Directions for Institutional Research: Enhancing Management of Fund Raising, 51, (pp. 39-53). San Francisco, CA: Jossey-Bass.

Garvin, D.A. (1980). The economics of university behavior. Toronto, ON: Academic Press.

Hansmann, H.B. (1981, Autumn). Nonprofit enterprise in the performing arts. The Bell Journal of Economics, 12, 341-361.

Hood, R.D., Martin, S.A., \& Oberg, L.S. (1977) Economic determinants of charitable donations in Canada. Canadian Journal of Economics, 10 , 653-669.

Kaplan, A.E. (1981). Giving U.S.A.: The annual report on philanthropy for the year 1980. New York, NY: AAFRC Trust for Philanthropy.

Kaplan, A.E. (1991). Giving U.S.A.: The annual report on philanthropy for the year 1990. New York, NY: AAFRC Trust for Philanthropy.

Kelly, K.S. (1991). Fund raising and public relations: A critical analysis. Hillsdale, NJ: Erlbaum.

Krashinsky, M. (1986). Transaction costs and a theory of the nonprofit organization. In S. Rose-Ackerman (ed.), The economics of nonprofit institutions: Studies in structure and policy. (pp. 114-132). New York, NY: Oxford University Press.

Lesley, L.L., \& Ramey, G. (1988). Donor behaviour and voluntary support for higher education institutions. Journal of Higher Education, 59(2), 115-132.

Loessin, B.A., Duronio, M.A., \& Borton, G.L. (1988). Questioning conventional wisdom. Currents, 14, 33-36.

Martin, S.A. (1975). Financing humanistic services. Toronto, ON: McClelland and Stewart.

Martin, S.A. (1985). An essential grace. Toronto, ON: McClelland and Stewart. Minton, F. (1995). You may be doing more than you think. Philanthropy, 12(3), 52-62. 
Mixer, J.R. (1993). Principles of professional fund raising. San Francisco, CA: Jossey-Bass.

Mount, J. (1996). Why donors give. Nonprofit Management \& Leadership, 7(1), $3-14$.

Newhouse, J.P. (1970). Toward a theory of nonprofit institutions: an economic model of a hospital. American Economic Review, 60, 64-74.

Oxford English Dictionary. (1989) Second Edition, Volume Xll. Oxford, England: Clarendon Press.

Odendahl, T. (1987a). Independent foundations and wealthy donors: An overview. In T. Odendahl (ed.), America's wealthy and the future of foundations, (pp. 1-26). New York, NY: Foundation Centre.

Odendahl, T. (1987b). Wealthy donors and their charitable attitudes. In T. Odendahl (ed.), America's wealthy and the future of foundations, (pp. 223-246). New York, NY: Foundation Centre.

Ostrander, S.A., \& Schervish, P.G. (1990). Giving and getting: Philanthropy as a social relation. In J. Van Til \& Associates (ed.), Critical issues in American philanthropy: Strengthening theory and practice, (pp. 67-98). San Francisco, CA: Jossey-Bass.

Panas, J. (1984). Mega gifts: Who gives them, who gets them. Chicago, IL: Pluribus Books.

Pickett, W.L. (1977). An assessment of the effectiveness of fund raising policies of private undergraduate colleges. Unpublished doctoral dissertation, University of Denver.

Presthus, R. (1962). The organizational society: An analysis and theory. A Caravelle Edition, Vintage Books. Toronto, ON: Random House of Canada Ltd.

Schervish, P.G. (1997). Inclination, obligation and association: What we know and what we need to learn about donor motivation. In D.F. Burlingame (ed.), Critical issues in fund raising, (pp. 110-138). Toronto, ON: John Wiley \& Sons, Inc.

Seymour, H.J. (1988). Designs for fund-raising, 2nd ed. Introduction by Charles Lawson. Ambler, PA: Fund-Raising Institute.

Sharp, D. (1994). A portrait of Canada's charities: The size, scope and financing of registered charities. Toronto, ON: Canadian Centre for Philanthropy.

Smith, C. (1994). The new corporate philanthropy. Harvard Business Review (May/June), 105-116.

Veblen, T. (1918). The higher learning in America: A memorandum on the conduct of university by businessmen. New York, NY: B.W. Huebsch. 
Webster's Third New International Dictionary. (1981). Unabridged. Springfield, MA: G. \& C. Merriam Co.

Weisbrod, B.A. (1988). The nonprofit economy. Cambridge, MA: Harvard University Press.

Woods, J.L. (1988). Factors associated with gift income in public research and doctoral granting institutions. Unpublished doctoral dissertation. Washington State University. 